\title{
The Effect of Combined Application of Poultry Manure and Sawdust on the Growth and Yield of Okra
}

\author{
Ogundiran Oluwasola Adekunle ${ }^{1}$ \\ ${ }^{1}$ Department of Agricultural Economic, Extension and Rural Development, University of Fort Hare, Alice 5700, \\ South Africa \\ Correspondence: Ogundiran Oluwasola Adekunle, Department of Agricultural Economic, Extension and Rural \\ Development, University of Fort Hare, Alice 5700, South Africa. Tel: 27-083-570-3601. E-mail: \\ ogundiranoluwasola@yahoo.com
}

Received: April 16, 2013 Accepted: July 4, 2013 Online Published: September 15, 2013

doi:10.5539/jas.v5n10p169

URL: http://dx.doi.org/10.5539/jas.v5n10p169

\begin{abstract}
The effect of combined application of poultry manure and sawdust on soil properties, growth and yield of okra (Abelmoschus esculentus (L.) Moench) were investigated at the main campus of Tai solarin University of Education Ijagun, Ijebu-Ode, Ogun State, Nigeria during 2010/2011 dry season. This size of the plot was $45 \mathrm{~m}$ by $5 \mathrm{~m}$; the seed was planted with three seed per hole at a spacing of $0.5 \mathrm{~m}$. The total numbers of plots were 27 plots, for the avoidance of doubt; it comprises three treatments and each treatment was replicate three times. The treatments consisted of $0,5,10$ ton/ha Broiler litter (Poultry manure) and 0, 2, 5 ton/ha (sawdust). The results indicated a significant increase in growth parameters in those plants planted in $0,2,5$ ton/ha poultry manure plot than sawdust plot. However, treatments were laid out in a randomized complete block design (RCBD) with three replications. Data were collected on growth and yield parameters (plant height, stem girth and number of leaves) were increased significantly $(\mathrm{p}<0.05)$ as manure rates increased. Poultry manure at 10 ton/ha has significant increase in fruit yield of okra increase. The combined application of poultry manure and sawdust does not have effect on yield and fruit number of okra but there is a slight effect on plant height. Based on the findings of the experiments it could be deduced that poultry manure seems to promote higher growth and yield of okra. Thus, it should be recommended for farmers growing okra in region.
\end{abstract}

Keywords: Okra, poultry manure, sawdust, growth \& yield

\section{Introduction}

Okra (Albemoscus esculentus) is a popular home garden vegetable with no specific origin but widely grown throughout the tropics. It belongs to the family marlraceale and is a member of order marvels. Okra is also a vegetable crop commonly grown by peasant farmers in West Africa. Fruit call capsule when young are harvested with knife and used in soup preparation. Okra is herbaceous that is grown and harvested for consumption when matured. Both learners and fruits are normally eaten in Nigeria. For instance in Oyo State, the young leaves can be made to "ILASA SOUP" and the fruit can be made to "ILA" also a type of soup.

The "Igbos ethnic" use the fruits to make "Ogbona soup" beside the matured fruit can be sun dried for use out of the season. In Nigeria, however, as well as other developing tropical nation's okra and other Vegetable have considerable length of time remain primary and cheapest source of protein, mineral and vitamins particularly for the low income earner. In spite of okra dietary qualities, for what the economic potential of okra like most other tropical vegetable crops has been neglected because it does not fall to cash crop category; instead, it is treated as subsidiary crop.

Scarcity of water supply or rain has been a major problem to vegetable farmer especially during the dry season forcing concerned farmers jobless and subsequently losing appreciable amount of income during the dry period. Poultry manure or dropping referred to the waste product or material from poultry birds which spread over or mixed with soil to help plant and crop grow. Okra requires a long warm growing season. It is quite susceptible to first and will not there even when there is a continued cold spell. It grows in all types of soil thriving best, well matured soil with a p between 6.0 and 6.8. Okra is a good source of vitamin and mineral especially iodine, management of soil is a major approach for harassing the production of okra. Poultry manure contains high percentage of nitrogen and phosphorus for the healthy growth of plants (Ewulo, 2005). Okra production is very 
low in many developing countries. Most farmers rely mainly on innate fertility of the soil and in addition invest considerable amount of money so as to achieve a reasonable yield of okra. More so, best production of okra requires intensive management practices that conserve and manage soil and nutrients needed for maintaining soil and water quality). This study was carried out to examine the effectiveness of dried Broiler litter and sawdust application on soil properties, growth and yield of okra.

\subsection{Literature Review}

Adelana (1985) stated the production of okra and soil management recommendation cannot be evolved until the major properties influencing yield of okra. Okra is an erect crop which has the height of $2 \mathrm{~m}$ resembling other mallows. Its flowers are born single in the leaf axils on pedicle mot more than $2.5 \mathrm{~cm}$ long. It poses a typical malvaceous floral organization which cut off before the fruit ripens Kochhar (1981). Okra requires a long warm growing season, it is quite susceptible to frost and will not thrive even when there is a continued cold spell. It grows in all types of soil thriving best in a most, well matured soil with a $\mathrm{pH}$ between 6.0 and 6.8. Also a good source of vitamin $\mathrm{C}$ and minerals especially for iodine, management of soil is a major approach for increasing the production of okra. Ojeniyi and Dexter (1984) indicated that soil chemical properties did not vary significantly among tillage treatment. There is a series of very good reports on genetic studies in okra, especially from Nigeria researchers. Multivariate analysis of 14 characters (pod yield, branch per plant, leaves per plant, days to flowering, plant height at flowering and maturity, pods per plant, edible pod length and width, mature pod length, duration of flowering, life span, seeds per pod, 100 seed weight) of 30 genotypes collected from different geographical areas revealed no relationship between clustering pattern and geographical distribution of okra genotypes (Ariyo, 1987)

This confirm the inverse relationship between the properties the water content was heights in the untilled flat, probably due to reduce evaporation rate associated with its relatively high bulk density, the immediate effect of tillage is to increase macro porosity and evaporation of soil water. Difference in okra yield between ecological zones in Nigeria was associated with rainfall distribution. Most cultivates are adapted to high temperature throughout the growing period with little season floatation. Seed, no germinate occur below $16^{\circ} \mathrm{C}$. A mostly average temperature range of $20^{\circ} \mathrm{C}$ to $30^{\circ} \mathrm{C}$ is considered approximate $\mathrm{Singh}$ (1987). Okra is tolerant to wide range of rainfall, supplementary irrigation may be required up to the fruiting period, if the rainfall is marginal adequate to maintain vigorous growth most selection are well adopted to cultivation in the lowland tropic up to evaluation of $500 \mathrm{~m}$, many cultivar grown in the lowland humid tropic are adapted to short day light Tidal (1968). Marsh (1992) Confirmed that okra was sensitive to low temperature and developed poorly below $15^{\circ} \mathrm{C}$ which in terms of climate constrained its production. More, so it stated that most of the okra cultivar in latitude higher than the tropic is photoperiod sensitive.

Nitrogen is said to be the motor of plant growth (IFA/FAO, 2000) Organic matter is the ultimate determinant of the soil fertility in most tropical soils and this account for its use, the fertility of soil could be sustained with the addition of poultry manure (Ikpe \& Powel, 2002). Perkin et al. (1952) mention that average yield of Cajun delight was superior to that of the other cultivar the hybrids showed that their productive potential on all sowing date, surpassing "Clemson spineless". In early planting, the crop maintained maximum productive period was prolonged to 18-19 weeks. Heitholt et al. (1996) reported that row spacing did not affect yield of the early maturity, normal leaf cultivar. Okra leaf issoline was not included in test. Even through the fresh fruit yield in late planting date might be favourable the long period for achieving this result present an inconvenience. The commercial production of Okra in Mexico including Northern Tamaulipas and in general in all central South America has been based on the Variety Clemson Spineless type. Okra fruit is harvested for several weeks should cover the fresh market need Jones (1982).

The long fruiting period of the plant generate an intensive demand for manual harvest labour for reason; okra production has been largely relegated to countries with cheap and abundant hand labour Kolhe and Charam (1967). The long fruiting period of the plant generate an intensive demand for annual harvest labour for reason okra production has been largely relegated to countries with cheap and abundant hand labour. As okra production play a significant role in the economy as other annual crops, more attention should be accorded to the selection of high yielding cultivars for seed and edible fruits. Therefore, this study aims at investigating the effect of combined application of poultry manure and sawdust on the growth and yield of okra for improvement in vegetable production. Poultry litter is made out of poultry manure and beddings materials such as sawdust, wood shavings, and grass cuttings. These combinations provide an excellent source of nitrogen $(\mathrm{N})$, phosphorus $(\mathrm{P})$, potassium $(\mathrm{K})$ and sulphur (S). A common intercropping combination in southwest Nigeria is maize/okra relay cropping followed by watermelon or bush greens and jute mallow or fodder crop of sweet potato. Okra is suitable for intercropping with papaya and it also now cultivated as an irrigated crop during the dry season, where it is often produced in mixed cropping with onion and other crops (Adelana, 1986; Aiyelaagbe \& Jolaoso, 1992) Therefore, improving 
the genetic potential of indigenous vegetables like okra (Abelmoschus spp.) is major paramount. The purpose of the study is to investigate the effect of combined application of poultry manure and sawdust on the growth and yield of okra.

\section{Materials and Methods}

\subsection{Description of the Study Area}

This research study was carried out at the main campus of Tai solarin University of Education Ijagun, Ijebu-Ode. The campus is situated on the out skirt of Ijagun Town which is $06^{\circ}-57^{\circ} \mathrm{E}$ and about $45 \mathrm{~km}$ South to Ijebu-Ode Local farmer and market women with little or none formal Education with subsistence agriculture being their predominant occupation. Hence the farm plots were situated behind the college of E.T.F staff building. The farm site was often used for arable crop, the soil type is clay loam soil which drained and suitable for okra production. Ijebu Ode is a Local Government Area and city located in south-western Nigeria, close to the A121 highway. The city is located $110 \mathrm{~km}$ by road north-east of Lagos; it is within $100 \mathrm{~km}$ of the Atlantic Ocean in the eastern part of Ogun State and possesses a warm tropical climate. With an estimated population of 222,653 (2007). Ijebu-Ode has 39 Public Primary Schools, 14 Public Junior Secondary school, 13 public Senior Secondary Schools, 110 approved Private Nursery and Primary Schools and 22 approved Private Secondary Schools. It is the second largest city in Ogun State after Abeokuta. Since pre-colonial times it has been the capital of the Ijebu kingdom. The LGA has an area of $192 \mathrm{~km}^{2}$ and a population of 154,032 at the 2006 census.

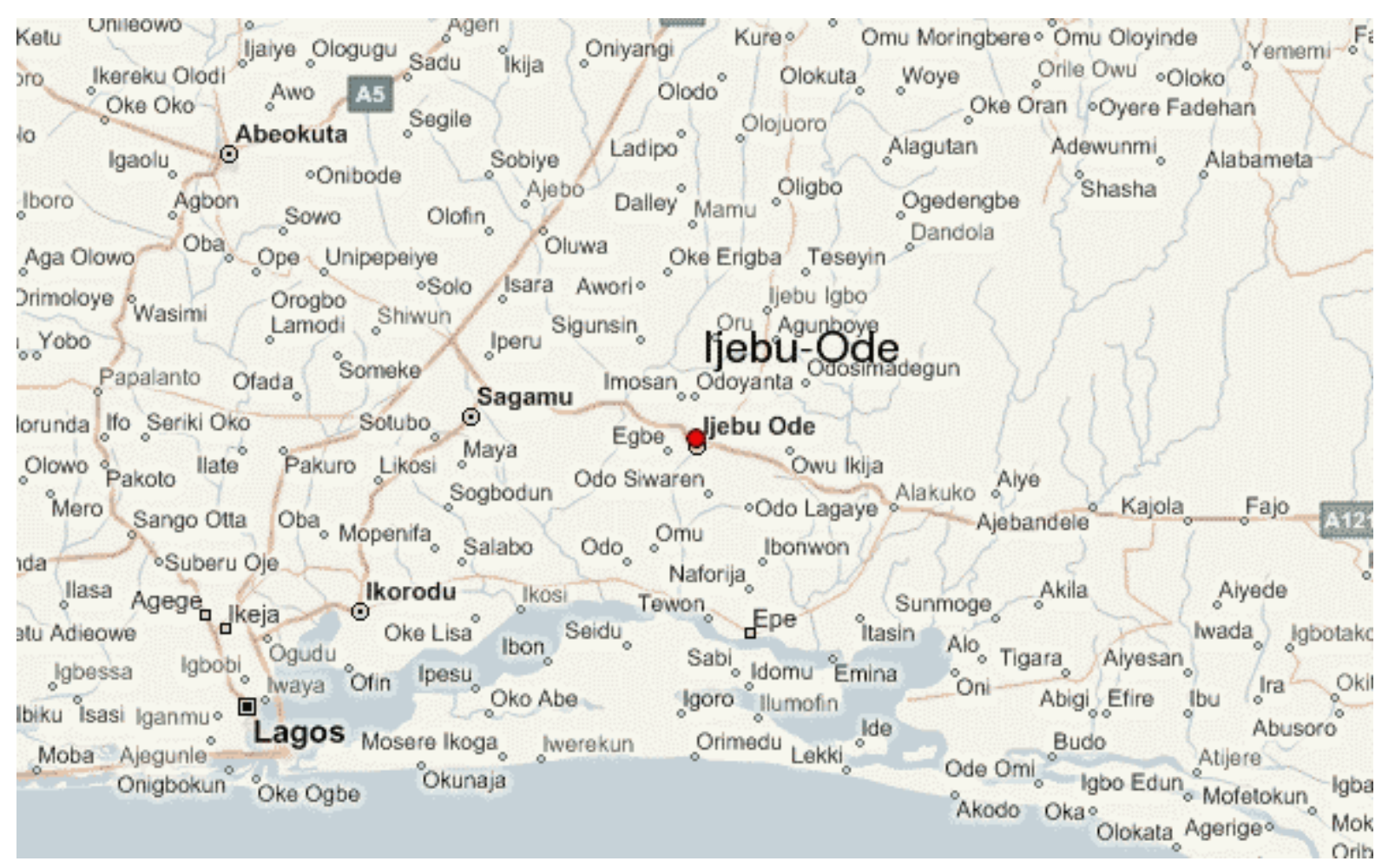

Figure 1. Map of Ijebu-Ode showing major Towns (Sources: www.collegeSA.co.za)

\subsection{Experimental Materials}

Soil sample were taken from a particular farm site which was planted with okra, which under goes different treatment. The soil sample of $0-15 \mathrm{~cm}$ deep was obtained from the okra plant for physiochemical analysis per plots these was carried out with the aids of the following, Pegs, Cutlass, Weighing scale, Measuring tape, ruler, book, which easy uptake of the soil samples. The farm land was divided into particular size and the plots on the farm were measured as $0.5 \mathrm{~m}$ X $5 \mathrm{~m}$ on which sample was collected. Statistical analysis was carried out on the data obtained for the soil sample to see whether there is significant difference in the various treatments adopted on the soil. Organic manures used for the study were saw dust which were collected from the same saw-mills in Ijebu ode town and pure and dried droppings of boiler's without beddings of wood shavings. 
Table 1. Some physical and chemical properties of the soil used for the study

\begin{tabular}{ll}
\hline $\mathrm{Ph}$ & 5.60 \\
\hline $\mathrm{Na}(\mathrm{cmol} \mathrm{kg}-1)$ & 1.02 \\
$\mathrm{~K}(\mathrm{cmol} \mathrm{kg}-1)$ & 0.18 \\
$\mathrm{Ca}(\mathrm{cmol} \mathrm{kg}-1)$ & 1.40 \\
$\mathrm{Mg}(\mathrm{cmol} \mathrm{kg}-1)$ & 0.91 \\
$\mathrm{ECEC} \mathrm{(cmol} \mathrm{kg-1)}$ & 3.51 \\
$\mathrm{~N}(\mathrm{cmol} \mathrm{kg}-1)$ & 0.31 \\
O.M (cmol kg-1) & 6.4 \\
Silt (\%) & 20.1 \\
Clay (\%) & 11.0 \\
Sand (\%) & 68.9 \\
\hline
\end{tabular}

The above table shows that the soil used for the study is generally low in fertilizer. The Ph however falls within the range optimal for crop production, make the soil suitable for the experiment. It also shows that the level of soil $\mathrm{pH}$ in the before the application of nutrient is much lighter than when poultry manure was applied. The soil contains both primary and secondary macro nutrients and the three groups of the soil particles are present in the soil, which are sand, silt and clay. Soil pH is good for the performance of okra yield, the ECEC is a properties of the soil that is largely controlled by soil $\mathrm{pH}$, increasing in the soil $\mathrm{pH}$ is raised and it is one of the most important chemical properties of the soil and it is closely related to soil fertility.

\subsection{Experimental Design}

The statistical design used for the study was Randomized Complete Block Design (RCBD) this comprised of three treatment and each treatments was replicated three times. The Organic Manure was poultry dropping and the inorganic manure was sawdust. The total number of plots were 27 plots, for avoidance of doubt treatment were: MPoultry Manure: $(0,2,5)$ ton/ha, S- Sawdust: $(0,5,10)$ ton/ha.

Table 2. The experimental design for the study

\begin{tabular}{ccc}
\hline Poultry Manure & Sawdust & \\
\hline $\mathrm{A}$ & $\mathrm{B}$ & Treatments \\
& 0 & $\mathrm{~A}_{1} \mathrm{~B}_{1}-0 \mathrm{M} \& 0 \mathrm{~S}$ \\
0 & 2 & $\mathrm{~A}_{1} \mathrm{~B}_{2}-0 \mathrm{M} \& 2 \mathrm{~S}$ \\
& 5 & $\mathrm{~A}_{1} \mathrm{~B}_{3}-0 \mathrm{M}$ \& 5S \\
& 0 & $\mathrm{~A}_{2} \mathrm{~B}_{1}-0 \mathrm{M} \& 0 \mathrm{~S}$ \\
5 & 2 & $\mathrm{~A}_{2} \mathrm{~B}_{2}-\mathrm{OM} \& 2 \mathrm{~S}$ \\
& 5 & $\mathrm{~A}_{2} \mathrm{~B}_{3}-0 \mathrm{M}$ \& 5S \\
& 0 & $\mathrm{~A}_{3} \mathrm{~B}_{1}-0 \mathrm{M} \& 0 \mathrm{~S}$ \\
10 & 2 & $\mathrm{~A}_{3} \mathrm{~B}_{2}-0 \mathrm{M} \& 2 \mathrm{~S}$ \\
& 5 & $\mathrm{~A}_{3} \mathrm{~B}_{3}-\mathrm{OM} \& 5 \mathrm{~S}$ \\
\hline
\end{tabular}

\subsection{Data Collection}

Data were collected through the test of the soil sample take from the Okra plants which are, effect of treatment on okra yields, number of fruits and the plant heights. This was done so as to determine the effect of combine application of poultry manure and sawdust in growth of okra yield. 


\subsection{Statistical Analysis}

Data obtained from the experiment were subject to statistical system (SAS) having designed study to fit into randomized complete block designed (RCBD).

\section{Result and Discussion}

Table 3 Show chemical composition of the poultry manure. They are composed nutrient such as $\mathrm{N}, \mathrm{P}, \mathrm{K}, \mathrm{Na}, \mathrm{Mg}$, C.N and C.

Table 3. Chemical composition of Boiler litter used on dry weight basis (DWS)

\begin{tabular}{ll}
\hline Properties & Value \\
\hline C. N (\%) & 7.00 \\
$\mathrm{~N}(\%)$ & 2.31 \\
Organic Carbon $(\%)$ & 18.10 \\
$\mathrm{Mg}\left(\mathrm{cmol} \mathrm{kg}^{-1}\right)$ & 0.61 \\
$\left.\mathrm{Na}(\mathrm{cmol} \mathrm{kg})^{-1}\right)$ & 0.07 \\
$\mathrm{P}(\mathrm{ppm})$ & 1.02 \\
$\mathrm{~K}\left(\mathrm{cmol} \mathrm{kg}{ }^{-1}\right)$ & 1.22 \\
\hline
\end{tabular}

Table 4. The effect of different level of manure on the yield, fruit number and plant height of okra

\begin{tabular}{cccc}
\hline Manure (ton/ha) & Yield (kg) & Fruit number & Plant height $(\mathrm{cm})$ \\
\hline 0 & $.5033^{\mathrm{ab}}$ & $18.444^{\mathrm{a}}$ & $17.080^{\mathrm{b}}$ \\
5 & $.3078^{\mathrm{b}}$ & $11.889^{\mathrm{a}}$ & $17.540^{\mathrm{b}}$ \\
10 & $.8600^{\mathrm{a}}$ & $24.556^{\mathrm{a}}$ & $26.003^{\mathrm{a}}$ \\
\hline
\end{tabular}

The above show the result of the effect of different levels of manure indicate that no significant effect on fruit number of okra, but slight effect on the yield and plant height. Plant height has no effect at 10 ton/ha manure while it has effect on others, it show that the levels of sol, manure in the soil before the application of nutrients is much lighter than when fertilizer or manure was applied. The application of 10 ton/ha has the highest figure which prove that when we applied it for okra production were going to have good yield at harvest period.

Table 5. The effect of different levels of sawdust on the yield, fruit number and plant height of okra

\begin{tabular}{llll}
\hline Sawdust (ton/ha) & Yield $(\mathrm{kg})$ & Fruit number & Plant height $(\mathrm{cm})$ \\
\hline 0 & $0.6211^{\mathrm{a}}$ & $20.778^{\mathrm{a}}$ & $19.961^{\mathrm{a}}$ \\
5 & $0.5278^{\mathrm{a}}$ & $15.111^{\mathrm{a}}$ & $20.459^{\mathrm{a}}$ \\
10 & $0.5222^{\mathrm{a}}$ & $19.000^{\mathrm{a}}$ & $20.203^{\mathrm{a}}$ \\
\hline
\end{tabular}

The result findings above reveals that table the effect of different level of sawdust on yield, fruit number and plant height of okra, the result indicate that there is no significant different in the treatment adopted in the experiment due to sawdust that contain wood or wood carving which does not has anything to do with production of okra in term of yield, fruit number and plant height but vary in figures, more so sawdust is not easily decomposed in soil. 
Table 6. The effect of combined different levels of manure and sawdust on the yield, fruit number and plant height of okra

\begin{tabular}{lllll}
\hline Manure (ton/ha) & Sawdust (ton/ha) & Yield (kg) & Fruit number & Plant height \\
\hline \multirow{3}{*}{0} & 0 & $.5833^{\mathrm{a}}$ & $23.33^{\mathrm{a}}$ & $19.447^{\mathrm{abc}}$ \\
& 2 & $.3933^{\mathrm{a}}$ & $13.00^{\mathrm{a}}$ & $16.487^{\mathrm{bc}}$ \\
& 5 & $.5333^{\mathrm{a}}$ & $19.00^{\mathrm{a}}$ & $15.307^{\mathrm{c}}$ \\
5 & 0 & $.2333^{\mathrm{a}}$ & $10.00^{\mathrm{a}}$ & $15.683^{\mathrm{c}}$ \\
& 2 & $.2067^{\mathrm{a}}$ & $07.67^{\mathrm{a}}$ & $18.409^{\mathrm{abc}}$ \\
& 5 & $.4833^{\mathrm{a}}$ & $18.00^{\mathrm{a}}$ & $18.530^{\mathrm{abc}}$ \\
& 5 & $1.0467^{\mathrm{a}}$ & $29.00^{\mathrm{a}}$ & $24.753^{\mathrm{ab}}$ \\
& 0 & $.9833^{\mathrm{a}}$ & $24.67^{\mathrm{a}}$ & $26.483^{\mathrm{a}}$ \\
& 2 & $.5500^{\mathrm{a}}$ & $20.00^{\mathrm{a}}$ & $26.770^{\mathrm{a}}$ \\
\hline
\end{tabular}

From the table above, it show that the combine application of manure and sawdust at different level does not has significant effect in yield and fruit number of okra because sawdust is not easily decomposed in the soil but vary in figures due to the variation in the quantity of manure and sawdust applied to each ridges. The result shows that there were no significant difference in the treatment adopted in the experiment but there is a slight effect on the plant height. According to the combine application of manure and sawdust at 10 ton/ha has the highest effect on plant height of okra follow by application of manure and sawdust at 5 ton/ha while application of manure and sawdust at 0 ton/ha has the least effect on plant height of okra.

\section{Conclusion}

The application of poultry manure had a significant effect on plant height, number of leaves per plant and fresh pod weight of okra grown under irrigation during 2010/2011 dry seasons at the Tai Solarin University of Education farm. The results obtained revealed that okra responded well to the application of poultry manure compared to sawdust which is not easily decomposed in the soil. Based on the finding of this study, it may be recommended that applying dried poultry manure was adequate for maximum growth parameters studied of okra production. For optimum performance of okra, under a low input system, an early application of compost manure of 10 ton/ ha on okra planted on heap or bed, depending on the quality of compost will be appropriate for sustainable production. More so, these organic materials which are presently being wasted, can be converted to wealth by using them as organic fertilizers.

\subsection{Policy Recommendations}

I hereby recommend that the dried poultry manure, which is not mixed with shriving wood is advisable for planting of okra and the application should be at 10 ton/ha for better yield of okra production in the study area.

\section{References}

Adelana, B. O. (1985). Effect of N.P.K fertilizer on the yield of okra in South Western Nigeria. Samaru journal of $\begin{array}{lllll}\text { Agricultural Research, } & 3, & 67-72 . & \text { Retrieved } & \text { from }\end{array}$ http://www.academicjournals.org/ajar/PDF/pdf2013/25Feb/Udengwu.pdf

Adelana, B. O. (1986). Evaluation of maize and okra mixed cropping in Nigeria. Ghana J. Agric. Sci., 14-19.

Aiyelaagbe, I. O. O., \& Jolaoso, M. A. (1992). Growth and yield response of papaya to intercropping with vegetable crops in South Western Nigeria. Agro for. Syst., 19, 1-14.

Akinsanmi, O. (1975). Soil Composition and Properties Certificate Agricultural Science.

Amusan, O. A. (2000). Principle and Management of Soil Fertilizer, (xi), 173-184.

Ariyo, O. J. (1987). Multivariate analysis and the choice of parents for hybridization in okra (Abelmoschus esculentus (L.) Moench). Theories Appl. Genet, 74, 361-363.

Ariyo, O. J., Akenn'ova, M. E., \& Fatokun, C. A. (1987). Plant character correlation and depth analysis of pod okra yield in okra. Emphatically, 36, 682-686.

Champman, H. D., \& Pratt, P. F. (1992). Method of analysis of soil, plant and water. Div. Agric. Sci. University California, Davic C.A, USA, PF.28. 
Diaz, F. A. A., Oregon, M., \& Leora, J. G. (1997). Fruit characteristic and yield of new okra hybrid and sub, Tropical Plant Science, 49, 8-11.

Ewulo, B. S. (2005). Effect of poultry and cattle manure on sandy clay loam soil. J. Anim. Vet. Sci., 4, 839-841. Retrieved from http://www.isfae.org/scientficjournal/2010/issue2/pdf/environment/e24.pdf

IFA/FAO. (2000). Fertilizer and their use. FAO Rome Italy. Retrieved from http://www.fertilizer.org

Ikpe, F. N., \& Powel, J. M. ( 2002). Nutrient cycling practices and changes in soil properties in the coop-livestock farming systems of Western Nigeria. Republic of West Africa. Nut. Cyc. Agroecosyst., 62, 37-45. Retrieved from http://www.iosrjournals.org

Jones, J. E. (1982). The present state of the art and science of cotton breeding for leaf morphological type (pp. 93-99).

Kolhe, A. K., \& Charm, V. M. (1967). Development of fruit yield capacity and influence of the fruit maturity on the reproductive and vegetative behaviour in okra (Abelmoschi esculents (L) Moench), Indian J. Agricultural Science, 37, 155-166.

Marsh, L. R. (1992). Emergence and seedling growth of okra genotypes at low temperature. Hortscience, 37, 1310-1312.

Marsh, L., Jones, R., \& Ellensieck, M. (1990). Growth regulations. Hortscience, 25, 431-433.

Ojeniyi, S. O., \& Dexter, A. R. (1984). Explain of soil structure on soil water status and tillage Research, 4, 371-379.

Perkins, D. V. J., Miller, C., \& Dally, S. L. (1952). Influence of pod maturity on vegetative and reproductive behaviour of okra. Hortscience, 60, 311-314.

Robbins, R. (1982). Guide to okra production. Avenge-Grower, 30, 7-10.

Singh, B. (1987). Effect of irrigation on the growth and yield of okra. Hortscience, 22, 879-880.

Sionit, N. B., Strain, R., \& Beekford, H. A. (1981). Environmental controls on the growth and yield of okra. Effect of temperature and of $\mathrm{Co}_{2}$ enrichment cool temperature. Crop Sci, 21, 885-888. http://dx.doi.org/10.1007/BF02187200

Tindall, A. L. (1968). Chemical composition of common tropical vegetable. Crop science, 4, 550-557.

Tisdale, S. L., Welson, W. L., Beaton, J. D., \& Halin, J. H. (1995). Soil fertility and fertilizer prentice hall of Indian pot Itd, new Delly.

\section{Copyrights}

Copyright for this article is retained by the author(s), with first publication rights granted to the journal.

This is an open-access article distributed under the terms and conditions of the Creative Commons Attribution license (http://creativecommons.org/licenses/by/3.0/). 